\title{
Institutional repository as an information infrastructure for scholarly communication: An exploratory study in Indonesia
}

\author{
L.Nurdin ${ }^{1 *}$ and S.Mukhlis ${ }^{2}$ \\ ${ }^{1}$ Department of Library \& Information Science, \\ Faculty of Adab and Cultural Sciences, \\ UIN Sunan Kalijaga, Yogyakarta, INDONESIA \\ ${ }^{2}$ University Library, Janabadra University, Yogyakarta, INDONESIA \\ e-mail: *nurdin@uin-suka.ac.id (corresponding author); mukhlis@janabadra.ac.id
}

\begin{abstract}
The objective of this study was to understand the proper implementation of the institutional repositories (IRs) as an infrastructure for scholarly communication. The study employed a descriptive-qualitative approach to explore how the IRs are operated in three selected universities in Indonesia. Three types of data collection techniques were used: interviews, observation, and document analysis. Structured interview was used as the main data collection technique. Findings of the study are presented in four main aspects in the implementation of IRs, i.e. development of scientific works; processing or recruitment of scientific works through self-archiving and digitization; promotion of IRs in increasing its visibility; and distribution or dissemination of the local scientific works by libraries. Although all three universities have adopted an open access policy which requires their academic community to make their scholarly works available in the freely accessible IRs, the distribution model differs in terms of the degree of openness. It seems that the value of a repository and open access ideals are quite enough to significantly increase faculty and students participation to populate the IRs. This study is significantly useful for readers, especially in the context of a developing country, to know the crucial position of the IRs as an infrastructure that frames the scholarly communication at universities.
\end{abstract}

Keywords: Institutional Repositories; Scholarly Communication; Information Infrastructure; Academic libraries.

\section{INTRODUCTION}

The Ministry of Higher Education (2015) Indonesia in its regulatory standard described the academic library as an integral part of the university that supports educational activities, research and community service. A librarian serves as a strategic information manager who supports the development of intellectual and scientific heritages. This development is the main focus of higher learning institutions, which demand the academic libraries to play a role as an information and knowledge centre that competes to build institutional repositories (IRs) in managing their scholarly works. IRs at this point become important in the management of scientific output with resources that not only to be stored, but also learnt, studied, and used as a basis of scientific development and preservation of university scholarship (Sutarno 2005; Pendit 2008; Miller 2017). Thus, IRs offer a suite of services that 
include application, organization, access, distribution, and preservation of digital contents (Chang 2002; Ratanya 2017). Likewise, IRs are conceptualized as a governance of scientific publications in digital format resulted from intellectual activities of an institution (Bansode 2011; Rozum and Thomas 2016). IRs in this case have become a strategic space for scholarly exchange within academia. In research activities, for example, a researcher acts as an information producer that produces scholarly works in the form of scientific ideas which are then communicated in the form of scientific publications. Developing scientific communication requires an information infrastructure that not only serves as a means of managing scientific works, but also as a means of disseminating knowledge. The information infrastructure is the use of information technology resources as a means of exchanging information and communication between various organizations (Bryd and Turner 2000). Those information technology resources serve to collect, repackage, and preserve intellectual products generated by universities and their cooperation with various institutions which are one of the functions of institutional repositories (Abrizah, Noorhidawati and Kiran 2010; Finn 2013). At this point, IRs as an information infrastructure that supports the process of scholarly communication show several things. As a basis for knowledge management, IRs provide a platform where scientific works are processed and a new dynamic range of knowledge emerges for scientific development. It is also important in relation to knowledge promotion that demonstrates scientific works of institutions in order to create an atmosphere of scholarly communication and increase institutional visibility.

An interesting point that is understandable in the explanation above is that the existence of IRs as an information infrastructure is concerned with the development of scientific works as a fundamental part of institutional repository governance. Rubin (2004) explained that the information infrastructure is a part consisting of institutions and individuals which are involved in a linear manner. Multi-stakeholder engagement will help users to obtain accurate, relevant, effective, and efficient information and become an attraction for reading and learning. Therefore, the $I R$ as an infrastructure of scholarly communication is expected to optimize its function to support research activities and open access as widely as possible (Oguche 2018; Spezi et al. 2017).

In addition, the aspect of processing scientific works is also important because they are not only organized systematically, but also can be retrieved quickly and precisely. In order to support the process of scholarly communication, scientific collections need to be promoted and exhibited. In this regard, the issues of distribution and service have become inseparable elements. Through the distribution element, knowledge will spread and develop. This distribution includes the repository contents that can be accessed online. The existence of repositories which provide online access enables not only the the distribution of scientific works, but also facilitate service programming activities and indexing of scholarly works (Arshad and Ameen 2017). According to Hasugian and Rabita (2005), information infrastructure is a process of exchange and access of information through computer networks so that organizations and individuals can share and access information widely through internet. In addition, the information infrastructure is a collection of systems that provide a variety of information sources and act as a place for community activities (Setiawan 2014). Furthermore, the infrastructure in a real life is often associated with public facilities, particularly libraries, which are visited by many people (Komariah, Yusup, and Saepudin 2009; Finn 2013). The presence of a repository as an information infrastructure in a scholarly communication will provide inexpensive access and reduce a gap of communication between the rich and the poor (James 2001). In short, those concepts show the importance of the existence of information infrastructure as a vital

Page | 102 
building to support access and exchange of information. Moreover, the development of technology provides opportunities and convenience for the community, both increasingly on access and exchange of information using gadgets and smart phones. As a result, information can be accessed in anywhere and anytime (Liauw and Genoni 2017).

In relation to that point, Abrizah, Noorhidawati and Kiran (2010) argued that IRs around the world are experiencing significant developments, particularly in terms of the number and volume of scientific works. The magnitude of the amount is seen from various types of scientific works that are deposited on a regular basis every year. In such situations, knowledge will spread and be generated as a new and dynamic knowledge. For this, IRs will become an important space for the knowledge and ultimately has implications for the pace of scholarly communication, locally, nationally, and internationally. As a manager of information that supports the development of intellectual property and knowledge, university libraries need an information infrastructure that serves to collect, repackage, and disseminate intellectual products. Salmon and Smart (2012) suggested several roles of libraries and/or repositories in building an infrastructure for scholarly communication. Among them is that the repository will become a common space for the community, especially the society of academicians in their interaction amongst colleagues. Likewise, access to knowledge for them will become broader, not only on the works of publication widely but also on the gray material collection. The plagiarism discourse amongst academic community members will also be addressed through digital repositories, where each contributor of knowledge will be careful in terms of their publications, especially those are potentially considered as plagiarised. In addition, the repository as an information infrastructure will become a self-publishing avenue which is not regulated by rigidly technical rules whose impact will accelerate the development of scholarly communication.

There are several motivations that encourage an institution to build its repositories, for instance, IRs can be used to monitor the productivity of the academic community members in relation to their scientific publications (Yi-Ping and Tsu-Jui 2018). Besides preservation of scholarly works, they also enable the works to be accessed easily (Kamraninia and Abrizah 2010). Those motivations finally enable the IRs to store the collections of institutions as good as possible (Callicott 2016; Nurcahyadi 2014). Based on the exploration of the concept, it can be understood that an IR is one of the services organized by the library to manage and serve digital information generated by the community served. If the $I R$ is managed by a university library, then the community of academicians served will get information about their own community and build communication in an academic environment (Oguche 2018). The works of the community according to Pertiwi (2013) are a research works, such as national or international scientific journal articles, thesis, dissertation, and so on. As a concept of scientific publication governance in digital format, IRs act as a means of information exchange. In order to support this process, IRs have been developed through information technology resources whose development rests on a concept called information infrastructure.

In order to support these activities, the repositories require good governance. This governance includes development, processing, promotion and distribution of the scholarly works. However, due to lack of funding and minimal staffing, libraries are essentially forced to creatively find solutions and, in some cases, develop their own systems. In addition to the development, the aspect of processing scientific works is also important. Management is related to the regulation of development of scientific works. In this aspect, scientific works files will be processed in accordance with the regulation applied in every library. Generally, the mechanism of this processing is more to about the aspect of uniformity of 
format, capacity, and type of file/media. Files of scholarly works that have been processed are being uploaded to the IRs. This process is aimed at promoting the works of institutions, both in print and born digital. Scientific works that are accessed and utilized by the academic community members will support the process of knowledge distribution because it is not only used, studied, and cited, but also communicated. Therefore, the IRs as an infrastructure for scholarly communication should be supported by considering those aspects because their existence is not only as a means of handing over the work, but also as a means of knowledge distribution (Arshad and Ameen 2017; Vickery and Vickery 2004). Hence, this research was conducted as an effort to understand the institutional repository as an infrastructure in the development of scholarly communication in selected university libraries in Indonesia.

\section{METHOD}

The objective of this study is to understand the proper implementation of the IR as an infrastructure for scholarly communication. The following research questions are posed:

(a) How are the resources developed?

(b) What are the processes involved in making the resources available?

(c) How do the libraries promote the institutional repositories to the users?

(d) How are the contents disseminated to the users?

To address the research questions, this study employs a descriptive-qualitative approach to explore how the institutional repositories are operated. Three IRs hosted by the Islamic universities (Universitas Islam Negeri, hereafter referred to as UIN) in Indonesia were purposively selected (UIN Sunan Kalijaga Yogyakarta, UIN Alauddin Makassar, and UIN Maulana Malik Ibrahim Malang) as the focus of this study due to the following reasons:

(a) They are from the same type of organization i.e. State Islamic Universities;

(b) They are located in three different geographical location in Indonesia.

(c) They are known to have implemented IRs that capture research output and other intellectual property generated by their constituent population active in many fields.

(d) The IRs are hosted by the academic libraries that manage the development, processing, promotion, and distribution of the IR resources.

This research employed three types of data collection techniques: interviews, observation, and document analysis. Structured interview was used as the main data collection technique. Observations involved gauging the level of diffusion and penetration of the repositories, their implementation and maintenance, the procedures involved in running the services and in supporting preservation strategies. Documented evidences on the establishment and implementation of the repositories were obtained. Data concerning rules and regulations, Standard Operational Procedures (SOP), and all matters related to the management of the institutional repositories were obtained from documents in Laugu's (2015) case study of institutional mandate. Data from observations and documents are supplemental means for corroborating interview findings.

As the study involved interviewing people who have particularly informed perspectives on the aspect of the institutional repositories being studied, two key informants from each university library were identified, comprising a librarian, and an IT staff (technologist). The technique for selecting the informants is purposive, by which the informants were selected based on the purpose and objective of a research (Arikunto 1991; Sugiyono 2012). Table 1 presents their demographic information.

Page | 104 
Table 1: Demographic Information of Informants

\begin{tabular}{|c|c|c|c|c|}
\hline $\begin{array}{c}\text { Informants } \\
\text { (Pseudonym) }\end{array}$ & Institution & Position & Education & Age \\
\hline Suhar & "UIN Sunan Kalijaga & Librarian & Bachelor degree & 44 \\
\hline Miyaz & UIN Sunan Kalijaga & Technologist & Bachelor degree & 30 \\
\hline Tamaf & UIN Alauddin & Librarian & Bachelor degree & 34 \\
\hline Hijbah & UIN Alauddin & Technologist & Bachelor degree & 27 \\
\hline Mufidin & UIN Maulana Malik Ibrahim & Librarian & Bachelor degree & 42 \\
\hline Imron & UIN Maulana Malik Ibrahim & Technologist & Bachelor degree & 29 \\
\hline
\end{tabular}

Data captured in field notes and audio recordings obtained from the three data collection techniques were processed in three stages namely: data reduction, display, and verification/conclusion (Denzin and Lincoln 1994; Miles and Huberman 1994). In data reduction, data that were considered incompatible with the focus of the research were put aside. This process was carried out a few times as an effort to verify data to get only consistent and coherent descriptions pertinent to the research questions. To draw conclusion from the data, a good display of data in the forms of charts and tables was created to facilitate understanding. The initial conclusions were then verified through references to the existing field notes or further data collection and member-checking procedures, to allow developing conclusions regarding the study. To ensure the validity of the data obtained, data were triangulated based on the three data sources and cross checking between the two informants from each university.

\section{Observations of the Institutional Repositories}

All three IRs are hosted by the academic libraries that have a strong commitment to provide an easy access, especially scientific works in digital format produced by the members of the academic community. The library of UIN Sunan Kalijaga Yogyakarta first implemented a digital library platform in 2007 using Ganesha Digital Library (GDL) software developed by the Indonesian Digital Library Network (IndonesiaDLN). Along with the open access movement which aims at providing free access to scholarly literature, facilitated by common technical standards and open source software, the library has migrated to EPrints since May 2012. The implementation of this software is considered to be easy and fast and the librarians at UIN Sunan Kalijaga Yogyakarta in general felt that the IR is an indispensable component of information and knowledge sharing at the university.

The UIN Maulana Malik Ibrahim Malang's IR was set up in 2010, as a basis to collect, preserve and disseminate the scientific works of the university community. The performance of the repository service has attracted the attention of the university management, as such the Rectorate Department since 2013, has been involving the Library Director in various meetings that discuss policies related to information access provision. In 2015 the university senate unanimously agreed on an Open Access (OA) policy granting the university a nonexclusive license to preserve a copy of published scholarly output in the IR, making it accessible to the public and greater research community. This also requires students to submit their research works in the form of undergraduate academic projects, Masters dissertations and Doctoral Theses to the IR which operates on the open source platform E-Prints. Building on the initiatives by the other two universities, UIN Alauddin Makassar library deployed the university's IR in March 2016. Through the Vice Rector of Academic Affairs, an Open Access team of librarians was officially formed through a decree that was signed by the university Rector in February 2017. The challenge and goal of this team is scaling repository operations by gathering author content and encouraging faculty 
to submit their research output, especially publications. In the past years, the IRs have expanded to include content other than theses and dissertations, such as journals, conference proceedings and books (Table 2). It seems that the value of a repository and open access ideals are quite enough to significantly increase faculty and students participation to populate the IRs (Table 3). Increasing the number of contents and contributors is expected to support the continuity of the scholarly communication process at the three universities.

Table 2: Number of Scholarly Works at the Three Institutional Repositories

\begin{tabular}{|c|c|c|c|}
\hline $\begin{array}{c}\text { Types of } \\
\text { Scholarly Works }\end{array}$ & $\begin{array}{c}\text { UIN } \\
\text { Sunan Kalijaga } \\
\end{array}$ & $\begin{array}{c}\text { UIN } \\
\text { Alauddin Makassar }\end{array}$ & $\begin{array}{l}\text { UIN Maulana Malik } \\
\text { Ibrahim Malang }\end{array}$ \\
\hline Bachelor thesis & 24,329 & 3,846 & 1,174 \\
\hline Master thesis & 1,865 & 475 & 43 \\
\hline Dissertation & 270 & 44 & 41 \\
\hline Journals & 684 & 14 & 10 \\
\hline Proceedings & 175 & 56 & 1 \\
\hline Books & 119 & 126 & - \\
\hline
\end{tabular}

Source:

http://digilib.uin-suka.ac.id (10/11/2017, 09:59 AM);

http://repositori.uin-alauddin.ac.id/(10/11/2017, 08:50 AM);

http://repository.uin-malang.ac.id/ (10/11/2017, 16:20 PM).

Table 3: Number of Contributors at the Three Institutional Repositories

\begin{tabular}{|c|c|c|c|}
\hline Contributors & $\begin{array}{c}\text { UIN } \\
\text { Sunan Kalijaga }\end{array}$ & $\begin{array}{c}\text { UIN } \\
\text { Alauddin Makassar }\end{array}$ & $\begin{array}{l}\text { UIN Maulana Malik } \\
\text { Ibrahim Malang }\end{array}$ \\
\hline Students & 71,775 & 4,365 & 1,105 \\
\hline Lecturers & 1,731 & 152 & 1,275 \\
\hline
\end{tabular}

Source:

http://digilib.uin-suka.ac.id (10/11/2017, 10:39 AM);

http://repositori.uin-alauddin.ac.id/ (10/11/2017, 10:50 AM);

http://repository.uin-malang.ac.id/ (10/11/2017, 15:25 PM).

\section{RESULTS AND DISCUSSIONS}

Findings of the study are presented in four main aspects in the implementation of IRs, i.e. development of scientific works; processing or recruitment of scientific works through selfarchiving and digitization; promotion of IRs in increasing its visibility; distribution or dissemination of the local scientific works by libraries

\section{(a) Development of Scientific Works}

The implementation of IRs at the three university libraries is considered a new development under the country' Islamic higher education. This is a good indication in the way to increase access to scientific works in order to build a scholarly communication infrastructure under the Ministry of Religious Affair in particular and in Indonesian Higher education in general. IRs governance have been regulated by each university as follows:

(a) The development of UIN Sunan Kalijaga Yogyakarta repository had been reinforced through the Decree of Rector No. 5 Year 2015 about the obligatory deposit of members of the academic community works to the university library. This decree is the main basis for regulation of the development of scientific publications at the library. The regulation is not only as a reference to enrich the contents, but also to promote the diversity of IR contributors.

Page | 106 
(b) UIN Alauddin Makassar library has developed its IR to manage their academic community scholarly works. The repository governance mechanism at the library is regulated through the Decree of Rector No. 08.A Year 2017 on Institutional Repository Guidelines. The library is fully responsible for any intellectual property deposited in the IR.

(c) UIN Maulana Malik Ibrahim Malang library has also implemented an open access policy using an IR system. Rules regarding the obligation to archive digital works authored by students are validated through the Decree of Rector in 2015. The works that must be submitted and deposited are the final research products of students and lecturers' scientific works.

Each university has a regulation in managing its academic community scientific works. Table 4 presents the depositing procedures for the three IRs. The regulation is an absolute requirement that must be fulfilled as a procedure of getting a library free-letter (fulfillment letter) amongst students who are going to complete their studies. The library free procedure at UIN Sunan Kalijaga Yogyakarta is independently done online. Similarly at UIN Alauddin Makassar and UIN Maulana Malik Ibrahim Malang libraries, the library free-letter is implemented to manage its collection for graduating students, and this provided through their institutional websites. The online final assignment regulations which enable the academic community members to upload files of their copyrighted works independently to the repositories are slightly different as described in Table 4.

Table 4: Depositing Procedures for the Institutional Repositories

\begin{tabular}{|c|c|c|c|}
\hline $\begin{array}{l}\text { Self-Uploading } \\
\text { Only }\end{array}$ & $\begin{array}{c}\text { UIN } \\
\text { Sunan Kalijaga }\end{array}$ & $\begin{array}{c}\text { UIN } \\
\text { Alauddin Makassar }\end{array}$ & $\begin{array}{l}\text { UIN Maulana Malik } \\
\text { Ibrahim Malang }\end{array}$ \\
\hline Login & $\begin{array}{l}\text { http://pustaka.uin- } \\
\text { suka.ac.id }\end{array}$ & $\begin{array}{l}\text { http://repositori.uin- } \\
\text { alauddin.ac.id/ }\end{array}$ & $\begin{array}{l}\text { http://repository.uin- } \\
\text { malang.ac.id/ }\end{array}$ \\
\hline File Upload & $\begin{array}{l}\text { Three types of files: } \\
\text { 1. First and last chapters } \\
\text { 2. Second to before last } \\
\text { chapter } \\
\text { 3. All files (full-text) }\end{array}$ & $\begin{array}{l}\text { 1. File upload for full-text, } \\
\text { based on strata. } \\
\text { 2. Filling in metadata } \\
\text { 3. Determining subjects }\end{array}$ & $\begin{array}{l}\text { Uploading full-text } \\
\text { File. }\end{array}$ \\
\hline Verification & $\begin{array}{l}\text { 1. Bookmark } \\
\text { 2. Watermark } \\
\text { 3. Administration } \\
\text { 4. Status for circulation }\end{array}$ & $\begin{array}{l}\text { 1. Bookmark } \\
\text { 2. Watermark } \\
\text { 3. Administration } \\
\text { 4. Status for circulation }\end{array}$ & $\begin{array}{ll}\text { 1. } & \text { Bookmark } \\
\text { 2. } & \text { Watermark } \\
\text { 3. Administration } \\
\text { 4. Status for } \\
\text { circulation }\end{array}$ \\
\hline End & Library free-letter & Letter of verification result & Library free-letter \\
\hline
\end{tabular}

Source:

http://digilib.uin-suka.ac.id (10/11/2017, 10:59 AM);

http://repositori.uin-alauddin.ac.id/ (10/11/2017, 11:50 AM);

http://repository.uin-malang.ac.id/ (10/11/2017, 14:25 PM).

In addition to the collection development through self-uploads (I.e. self-archiving), UIN Sunan Kalijaga Yogyakarta library also digitizes members of the academic community works, especially from the students projects, theses and dissertations which are not born digital; those works published before 2014. Besides enriching the repository contents, the library also aims to build a continuous publication in the repository as acknowledged by one of the informants. "Prior to enactment of self-upload regulation, the academic community members submit their final files in CDs and print format. Our task is to process the digital files based on the library standard, such as giving bookmark and watermark. Meanwhile, the works on printed formats, we digitize the works using automatic mediacopy scanner so that the process can be done quickly and practically" (Suhar). 
Similarly, an informant from UIN Alauddin Makassar remarked the importance of adhering to a standard procedure in archiving the digitized collections: "Most our collection, such as inscription, thesis and dissertation, that have not been formatted digitally, would be processed and deposited into our repository system. It is a requirement for us so that the students who have completed their studies can find their own works in our repository... and the most important thing in our mind is that all works of the academic community members' can be accessed" (Tamaf). Another informant from UIN Maulana Malik Ibrahim Malang echoed similar procedure: "The process of managing unedited old scientific works is a part of the library's priority other than current collection development. And we are required to work fast so that the old (past) works can be accessed through online" (Imron).

A similar process and procedure of the content development for scientific works applies to the academics' research output in all three libraries. The academics are given user accounts and passwords that can be used to submit their publications (either digitized or born digital) to the repository. If the manuscript is in printed format, the academics may either digitize it first and send the file to the library; or if they do not have the means and resources to do so, they may send the printed version to the library and the library will facilitate digitizing and submitting the file to the repository. In observing the content development process at the three libraries, it can be concluded that the libraries have a work-flow that facilitates members of the academic community to submit their past research works as well as current publications through self-upload function. In this process, the libraries have identified the file type and file format that make it easier for librarians to verify. Besides handling the handover of the works in digital forms, the libraries also encourage and facilitate the submission of past works that are in print, to ensure the continuity and diversity of the repository contents.

\section{(b) Processing or Recruitment of Scientific Works}

Scientific works which have passed verification would then be processed by the libraries. Verification is done by validating the works based on technical aspects, such as the completeness of pages and files. This requires a systematic procedure that not only facilitates the management of scientific works, but also their long-term archiving services. The regulatory portrait is reflected in the expression of an informant at UIN Sunan Kalijaga Library Yogyakarta: "To make an effective management for the repository, students who want to self-upload are required to upload three types of file formats to make it easier for the officers to verify and process for uniformity of format and file capacity (file size)" (Miyaz).

There are various ways that the libraries do to facilitate the processing of scientific works. An informant from UIN Alauddin Makassar described: "One of the thing that ease our services in managing scientific works is to create guidance on how to upload scientific works at our repository portal... for this, we hope that our students and other academic members can easily understand the minimum standard of library works that are required by our library. Besides, we provide pdf format tutorial as well as a video on YouTube. We do all these in order to minimize errors, especially in terms of file uniformity. As you know, if there are a lot of mistakes in associating the file standards, it may cause problems in terms of access... I think if such thing occurs it would be delayed to reach the users whereas the works are extremely needed by the academicians" (Hijbah).

In general, all informants emphasized the skills and knowledge (and time) required to perform their job satisfactorily in processing the scientific works. Observation of the mechanism of processing involving the identification, analysis and verification of the

Page | 108 
scientific works at these three IRs (Table 5) reflects a user-oriented service related to access, dissemination, and preservation of scholarly works, where the users are repository content creators and as eventual content users.

Processing of scientific works also covers the handover of the final record or document by the content creators, and the process from content creation to verification is regulated. The rules are aimed to ensure uniformity in the bibliographic and technical description of the works to aid in the discovery and identification of items. Content creators are also informed of the copyright so that they would become better stewards of their own copyrights, having the ability to self-archive their work in an institutional repository. The libraries may also do an embargo for some of the contents of the works based on the agreement with the content creators. During the embargo period, only non-embargoed contents could be accessed.

Table 5: Mechanism of Processing the Scientific Works at the Institutional Repositories

\begin{tabular}{|c|c|c|c|}
\hline $\begin{array}{l}\text { Mechanism of } \\
\text { Processing }\end{array}$ & $\begin{array}{c}\text { UIN Sunan Kalijaga } \\
\text { Yogyakarta }\end{array}$ & UIN Alauddin Makassar & $\begin{array}{l}\text { UIN Maulana Malik } \\
\text { Ibrahim Malang }\end{array}$ \\
\hline Identification & Bibliographic data of works & Metadata of works & Data of works \\
\hline Mapping & $\begin{array}{l}\text { Types of works \& } \\
\text { contributors }\end{array}$ & $\begin{array}{l}\text { Types of works \& } \\
\text { contributors }\end{array}$ & $\begin{array}{l}\text { Types of works \& } \\
\text { contributors }\end{array}$ \\
\hline Analysis & $\begin{array}{l}\text { Selecting keywords, } \\
\text { subject, \& division }\end{array}$ & $\begin{array}{l}\text { Selecting keywords, } \\
\text { subject, \& division }\end{array}$ & $\begin{array}{l}\text { Selecting keywords, } \\
\text { subject, \& division }\end{array}$ \\
\hline Tool Verification & $\begin{array}{l}\text { Bookmarks, watermarks, } \\
\text { merges, dan url files }\end{array}$ & $\begin{array}{l}\text { Bookmarks, watermarks, } \\
\text { merges, dan url files }\end{array}$ & $\begin{array}{l}\text { Bookmarks, watermarks, } \\
\text { merges, dan url files }\end{array}$ \\
\hline Finishing & $\begin{array}{l}\text { Records of received works } \\
\text { time including date, } \\
\text { month, and year }\end{array}$ & $\begin{array}{l}\text { Records of received works } \\
\text { time including date, } \\
\text { month, and year }\end{array}$ & $\begin{array}{l}\text { Records of received works } \\
\text { time including date, } \\
\text { month, and year }\end{array}$ \\
\hline
\end{tabular}

Source:

http://digilib.uin-suka.ac.id (10/11/2017, 10:57 AM);

http://repositori.uin-alauddin.ac.id/ (10/11/2017, 11:47 AM);

http://repository.uin-malang.ac.id/ (10/11/2017, 13:25 PM).

\section{(c) Promotion of the Institutional Repositories and the Scientific Works}

Scientific works that have been processed for discovery need to be promoted, because this would not only increase the visibility of the repository, but also the accessibility of the scientific works for users. Since IRs are an important part of supporting the sustainability of knowledge access and dissemination, the three libraries in this study emphasized the need for various strategies in reaching out to the campus constituencies to access and utilize the content of the repositories.

The library of UIN Sunan Kalijaga Yogyakarta promotes its IR in three ways: (a) The university library websites; (b) user education activities especially for new students; and (c) the library guide book. The importance of promoting the IR was emphasized: "Our promotion of the repository is important because new students who follow the user education activities will get information on how to use the $I R$, the rules, and what the contents are. Through the guide book, the library can teach members of the academic community about how to use library facilities, particularly how to search as well as inform them the procedure to upload their papers to the repository" (Suhar).

The library of UIN Alauddin Makassar conduct intensive promotion of the IR through outreach campus programmes and the library's social networking sites, such as Facebook, WhatsApp, Instagram, and Twitter. The library has a dedicated IR team that conduct 
thoughtful and active outreach efforts to engage the university community with the library's initiative: "The team not only informs and encourages the students and lecturers to submit their research works, but we always promote interesting scientific works to our users. For example, the library socializes gradually with the academic community, such as how to upload their works into repository. Also, we conduct seminars and workshops about the repository. Furthermore, some of our repository team members are lecturers so that through classroom and lectures, they will help promote, they talk about the IR and use the contents in their classrooms" (Tamaf).

The library of UIN Maulana Malik Ibrahim Malang focuses on its repository's portal to promote the full-text of its scientific works. The portal's simple and user-friendly interface is equipped with a feature of "cover preview" that is accompanied with a "direct download bottom" which is very helpful and intuitive to the users. It was thought that having such characteristics would be effective as a means of the repository promotion and it would spread among the campus constituencies by word-of-mouth. Such situation will have an impact on the visibility of the repository. The library also incorporate the IR content in its research training programme: "We are promoting scientific works through orientation activities for new students and training of ORS (Online Research Skill). The library utilizes these activities to introduce library facilities, especially repositories so that they have knowledge and experience whenever they need information, especially scientific works, to support their learning process" (Mufidin).

\section{(d) Distribution or Dissemination of Scientific Works}

The distribution of scientific works is an important part in providing access to members of the academic community to address their information needs for research programmes and learning activities at the universities. The library of UIN Sunan Kalijaga Yogyakarta has a regulation related to the distribution of the scholarly works through its IR (http://digilib.uin-suka.ac.id/). The intended regulation is to provide limited access to the contents of scientific works. The definition of access is based on the university rules regarding full text access, founded on a few considerations. First, opening up the scientific works has not been agreed at the highest university decision-making level due to the quality or standard of the works. Secondly, there are still complaints received from contributors or copy-right owners if their works could be accessed full text. Likewise, other considerations are related to privacy and copyright provision, and the distribution recognition system which is still an ongoing process of development until it reaches stability. Nevertheless, full text access remains open to the users through a rather bureaucratic control mechanism, reflected in the following verbatim. "In order to gain full access, they [students] can apply to the library after getting a recommendation letter from their supervisors and faculty. After verified and it is in accordance with the procedure, then they will be given full access account that can be used only for 24 hours" (Suhar).

The library of UIN Alauddin Makassar disseminates the scholarly works through the repository portal (http://repositori.uin-alauddin.ac.id/), where users can access the full range of scientific works based on various search strategies: "The distribution of scientific works through our repository portal is designed to meet their (users) diverse needs. It is hoped that this will foster familiarity for the users in conducting their scientific research through the institutional repository portal" (Tamaf).

Similarly, the library of UIN Maulana Malik Ibrahim Malang also distributes the university's research output through the repository portal (http://repository.uin-malang.ac.id/). The portal allows the users to download the full-text of the needed works. However, this

Page | 110 
convenience has become a scourge for the library, especially in relation to plagiarism. Even though, such plagiarism is finally not a barrier for the library to distribute its scientific works in a full text as expressed by an informant. "We believe that open access to the scientific works actually makes people careful and observant when they produce their works, especially when they include and cite other works into their writing. Full-text access will maximize the distribution of the scientific works. In addition to opening the wider access to contents, it also makes the repository portal as a place for the academics to rely on their expectations, especially the availability of current and credible scientific works" (Imron).

Although all three universities have adopted an open access policy which requires their academic community to make their scholarly works available in the freely accessible institutional repositories, the distribution model differs in terms of the degree of openness. One requires users to go through a tight bureaucracy control for full-text materials with limited temporal access, while the other two open up their full texts to their users. Apart from the different polices, in principal the universities recognize their IRs as an essential information infrastructure for scholarly communication in the development, processing, promotion and distribution of research output (Figure 2).

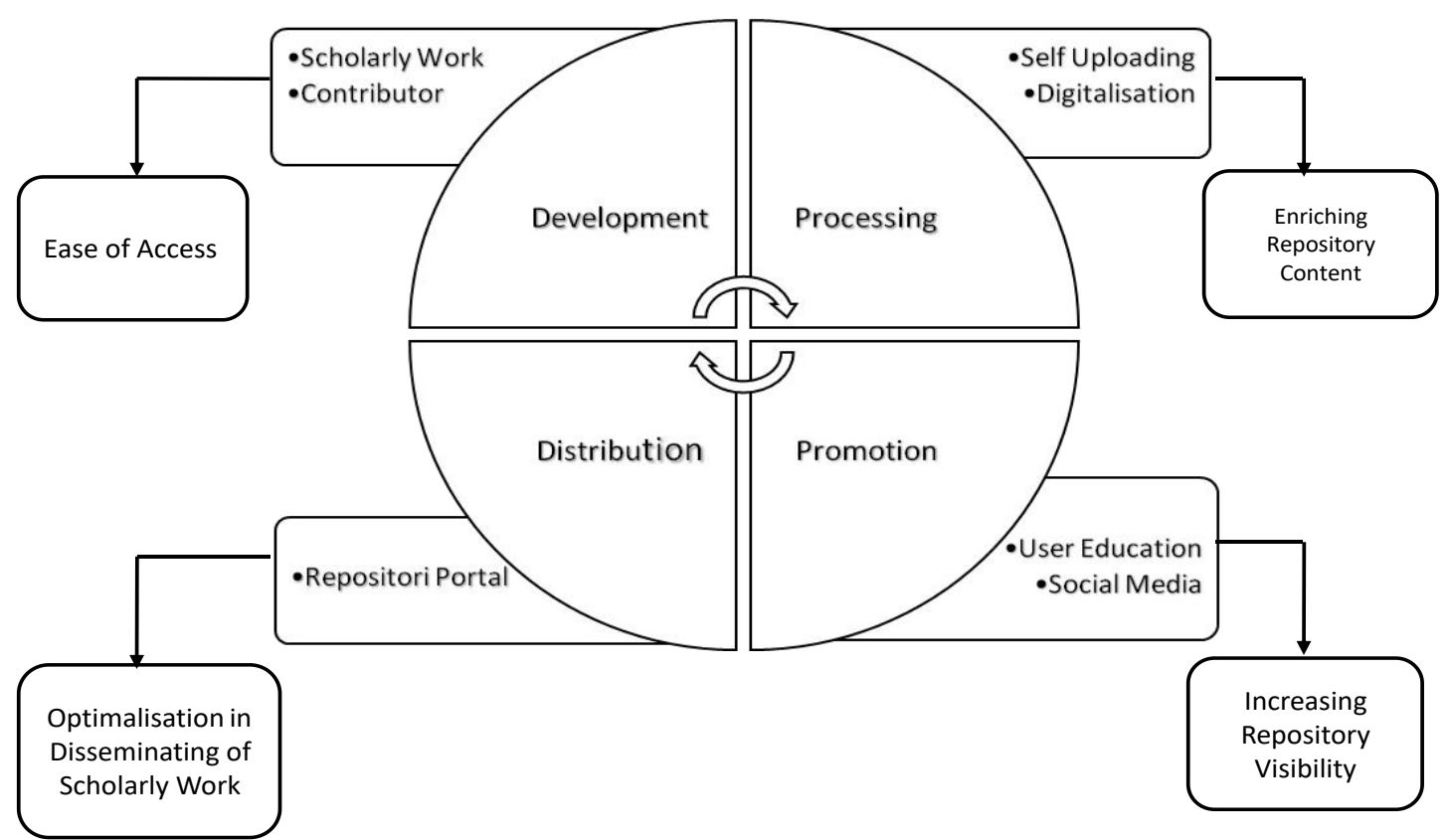

* Repositori Portal is the local name given to portals of Institutional Repository

Figure 2: Institutional Repository as an Information Infrastructure for Scholarly Communication

\section{CONCLUSION}

The presence of IRs as an infrastructure for scholarly communication contributes greatly to the dissemination of knowledge in the context of scholarly communication. As a basis for knowledge management, IRs require an effective and efficient management, particularly in the governance of scientific works that require systematic stages before reaching members of the academic community. These stages include the development of scientific works, 
recruitment as well as promotion and distribution to this community. The mechanism for the governance of the scientific works, such as the development, is regulated through a letter of decision from the institution leaders. Among them, as can be seen in the form of regulating the submission of the scientific works by members of the academic community to the libraries. Also, there are research output in the form of theses and dissertations, which need to be processed according to the rules and procedures of the respective institution, to facilitate both the identification of the works and their retrieval. Although in general, each institution has different rules and procedures, it still stands at a common access point that is the online access to the IR portals.

The IR portals also serve as a platform in the promotion and distribution of scientific works and they have become an important infrastructure for the continuity of scholarly communication at the three universities. In terms of the distribution of scientific works, it is found that all repositories provide widest access to full text to their users albeit with different policies. The repository of UIN Sunan Kalija serves its collection through a rather strict bureaucracy control because access to its full texts requires users to submit a special proposal to the library and the duration of permitted access is very limited. Unlike the other two IRs, the full text service is open to all their academic community members without having to go through a tight technical bureaucracy control. Unfortunately, the number of collections belonged to these two IRs is far below the number of collections populated in UIN Sunan Kalijaga Yogyakarta IR.

It should be noted that this study has not come yet to the conclusion whether or not the different number of collections motivates the differences in access regulation applied or it lies on the management and policy of each library, and even, of each university. Or, it may also be caused by differences in a campus learning atmosphere and a few other conditions that need to be further investigated. However, this study is significantly useful for readers, especially in the context of a developing country, to know the crucial position of the IRs as an infrastructure that frames the scholarly communication at universities.

\section{ACKNOWLEDGEMENT}

No grant from any public, commercial, or non-profit funding agency was offered for the conduct of this research. We thank the reviewers for their enriching comments to improve the article.

\section{REFERENCES}

Abrizah, A., Noorhidawati, A., and Kiran, K. 2010. Global visibility of Asian Universities' open access institutional repositories. Malaysian Journal of Library \& Information Science, Vol.15, no.3: 53-73.

Arikunto, S. 1991. Prosedur penelitian: Suatu pendekatan praktik [Research procedure: A practical approach]. Jakarta: Rineka Cipta.

Arshad, A. and Ameen, K. 2017. Scholarly communication in the age of Google: Exploring academics' use patterns of ejournals at the University of the Punjab. The Electronic Library. Vol. 35, no. 1: 167-184. Available at: http://dx.doi.org/10.1108/EL-09-2015-0171.

Bansode, S.Y. 2011. Developing institutional repository in university library: A case study of University of Pune. International Journal of Information Dissemination and Technology, 
Vol 1,no.4: 188-192. Available at: https://www.ijidt.com/index.php/ijidt/article/ view/32/32.

Bryd, A.T. and Turner, E.D. 2000. Measuring the flexibility of information technology infrastructure: Exploratory analysis of construct. Journal of Management Information System, Vol. 17, no. 1: 167-208.

Callicott, B. 2016. Peer review and institutional repositories. In Callicott B., Scherer D., \& Wesolek A. (Eds.), Making institutional repositories work (pp. 249-260). West Lafayette, Indiana: Purdue University Press. Available at: doi:10.2307/j.ctt1wf4drg.23.

Chang, S.H. 2002. Institutional repositories: The library's new role. OCLC Systems \& service, Vol. 19, no. 3: 77-79.

Denzin, N.K. and Lincoln, Y.S. 1994, Handbook of qualitative research. London: Sage Publications.

Finn, M. 2013. Information infrastructure and descriptions of the 1857 Fort Tejon Earthquake. Information \& Culture, Vol. 48, no. 2: 194-221.

Hasugian, J. dan Rabita, E. 2005. Infrastruktur informasi global dan dampaknya terhadap perpustakaan [Global information infrastructure and its effect on libraries]. Pustaka: Jurnal Studi Perpustakaan dan Informasi, Vol. 1, no. 2: 26-31.

James, J. 2001. The global information infrastructure revisited. Third World Quarterly, Vol 22, no 5: 813-822.

Kamraninia, K. and Abrizah, A. 2010. Librarians' role as change agents for institutional repositories: A case of Malaysian academic libraries. Malaysian Journal of Library \& Information Science, Vol. 15, no.3: 121-133.

Komariah, N., Yusup, P.M. and Saepudin, E. 2009. Perpustakaan sebagai target Corporate Social Responsibility (CSR) di Telkom University. Journal of Library \& Information Science, Vol. 9, no. 1: 1-11. Available at: https://ejournal.upi.edu/index.php/edulib/article/view/ 15553/pdf.

Laugu, N. 2015. Representasi kuasa dalam pengelolaan perpustakaan: Studi kasus pada perpustakaan perguruan tinggi islam di Yogyakarta [Power representation in library administration: A case study of Islamic Higher Teaching Libraries in Yogyakarta]. Yogyakarta: Gapernus Press.

Liauw, T.T. and Genoni, P. 2017. A different shade of green: A survey of Indonesian higher education institutional repositories. Journal of Librarianship and Scholarly Communication, Vol. 4, eP2136. Available at: http://dx.doi.org/10.7710/2162-3309.2136.

Miles, M.B. and Huberman, A.M. 1994. Qualitative data analysis. London: Sage Publications.

Miller, A. 2017. A case study in institutional repository content curation: A collaborative partner approach to preserving and sustaining digital scholarship. Digital Library Perspectives, Vol. 33, no. 1: 63-76. Available at: http://dx.doi.org/10.1108/DLP-07-20160026.

Ministry of Higher Education. 2015. Peraturan Menteri Riset, Teknologi, dan Pendidikan Tinggi Republik Indonesia Nomor 44 Tahun 2015 Tentang Standar Nasional Pendidikan Tinggi [Rules of the Minister of Research, Technology and Higher Education, Republic of Indonesia, Number 44 Year 2015 on Higher Education National Standard].

Nurcahyadi, I. 2014. Membangun institutional respository bagi perguruan tinggi seni: Catatan pengalaman UPT Perpustakaan Institut Seni Indonesia Yogyakarta [Development of an institutional repository for Arts Higher Teaching: An experience of UPT Library of Indonesian Arts Institute Yogyakarta]. Paper presented at the Forum Perpustakaan Perguruan Tinggi Indonesia DIY.

Oguche, D. 2018. The state of institutional repositories and scholarly communication in Nigeria. Global Knowledge, Memory and Communication. Vol. 67, no. 1/2: 19-33. Available at: https://doi.org/10.1108/GKMC-04-2017-003. 
Pendit, P.L. 2008. Perpustakaan Digital dari A sampai Z [Digital libraries from A to Z]. Jakarta: Cipta Karsa Mandiri.

Pertiwi, S.E. 2013. Aksesibilitas informasi e-Journal repository [E-journal repository information accessibility]. Majalah Visi Pustaka, Vol. 15, no. 2: 115-119.

Ratanya, F. C. 2017. Institutional repository: Access and use by academic staff at Egerton University, Kenya. Library Management, Vol. 38, no. 4/5, s017. Available at: http://dx.doi.org/10.1108/LM-02-2017-0018.

Rozum, B. and Thomas, B. 2016. Populating your institutional repository and promoting your students: IRs and undergraduate research. In making institutional repositories work (pp.311-318) West Lafayette, IN: Purdue University Press. Available at: https://digitalcommons.usu.edu/cgi/viewcontent.cgi?article=1248\&context=lib_pubs.

Rubin, R.E. 2004. Foundations of library and information science, $2^{\text {nd }}$ Edition. New York: Neal-Schuman Publisher.

Salmon, F. and Smart, C.A. 2012. The role of the academic library in facilitating scholarly communication. Caribbean Quarterly, Vol. 58, no. 2/3: 67-78.

Setiawan, E. 2014. Perancangan infrastruktur teknologi informasi pada sistem pengelolaan jaringan: Studi kasus PT AJN Solusindo [Information technology infrastructure planning on the network management system: A case study of PT AJN Solusindo]. Final Report. Faculty of Computer Science, Magister of Information and Technology of JakartaIndonesia.

Spezi, V., Pinfield, S.W.S., Fry, C.C.J., and Willett, P. 2017. Open-access mega-journals: The future of scholarly communication or academic dumping ground? A review. Journal of Documentation, Vol. 73, no. 2: 263-283. Available at: http://dx.doi.org/10.1108/JD-062016-0082.

Sugiyono. 2012. Metode Penelitian Kuantitatif, Kualitatif dan R\&D [Quantitative, qualitative and R\&D research method]. Bandung: Alfabeta.

Sutarno N.S. 2005. Tanggung Jawab Perpustakaan dalam Mengembangkan Masyarakat Informasi [Responsibilities of libraries in developing an information society]. Jakarta: Panta Rei.

Vickery, A. and Vickery, B.C. 2004. Information science in theory and practice. London: Butterworths.

Yi-Ping, L. and Tsu-Jui, M. 2018. Institutional repositories: A bibliometric study of the social sciences citation index (SSCI). The Electronic Library. Vol. 36, no. 3: 504-517. Available at: https://doi.org/10.1108/EL-09-2017-0192. 